\title{
High Frequency of HBeAg-Negative Cases in Naive HBsAg-Positive Subjects with Chronic Hepatitis B Virus Infection Managed in the Yaoundé Hepatitis Therapeutic Committee: A Cross Sectional Study
}

\author{
Firmin Ankouane*, Mathurin Kowo, Oudou Njoya, Elie Claude Ndjitoyap Ndam \\ Department of Internal Medicine and Specialties, Faculty of Medicine and Biomedical Sciences, University of \\ Yaoundé I, Yaoundé, Cameroon \\ Email: ${ }^{*}$ ankouaneandoulo@yahoo.com
}

Received 28 March 2015; accepted 4 May 2015; published 12 May 2015

Copyright (C) 2015 by authors and Scientific Research Publishing Inc.

This work is licensed under the Creative Commons Attribution International License (CC BY). http://creativecommons.org/licenses/by/4.0/

\section{(c) (i) Open Access}

\section{Abstract}

The aim was to describe the epidemiology of the chronic hepatitis B virus (HBV) infection within Yaoundé Hepatitis Therapeutic Committee. Methods: This was a cross-sectional study from June 2004 to May 2012. We consecutively collected epidemiological data (gender, age, alanine aminotransferase-ALT, HBe-antigen-HBeAg, hepatitis B viral load-HBV-DNA and cirrhosis evaluation) from naive hepatitis B surface antigen (HBsAg)-positive patients with chronic HBV infection. Chronic HBV infection is defined by the persistence of HBsAg for at least six months. The level of serum HBV-DNA was determined by the COBAS-AmpliPrep Technical/COBAS-TaqMan HBV ${ }^{\circledR} 2.0$ (Roche). Data were entered and analyzed using SPSS 20.0 software (IBM Corporation, USA). Results: Of the 315 HBsAg-positive patients consulted, $74.6 \%$ were male; mean (SD) age 35.04 (10.25) years. Nearly $92 \%$ were HBeAg-negative. The serum ALT level was normal in 63.2\%; HBV-DNA was detected in $81.0 \%$ and was $\leq 2000 \mathrm{IU} / \mathrm{mL}$ in $65.9 \%$. Liver biopsy was performed in $145(46.03 \%)$; 10 (6.9\%) had cirrhosis. HBeAg-negative patients were older than HBeAg-positive (35.3 vs. 31.9 years; $p=0.006$ ). The serum ALT level was high in $84.0 \% \mathrm{HBeAg}$-positive patients and in $32.8 \%$ HBeAg-negative ( $<0.0001)$. HBV-DNA was detected in $100 \%$ of HBeAg-positive patients against $79.7 \%$ of HBeAg-negative ( $p=0.05$ ). The median HBV-DNA level was $1550 \times 10^{3} \mathrm{IU} / \mathrm{mL}$ in $\mathrm{HBeAg}-$ positive patients and $1140 \mathrm{IU} / \mathrm{mL}$ in $\mathrm{HBeAg}$-negative $(\mathrm{p}<0.0001)$. Cirrhosis was diagnosed in $15.4 \%$ of $\mathrm{HBeAg}$-positive patients and in $6.1 \%$ of $\mathrm{HBeAg}$-negative $(\mathrm{p}=\mathbf{0 . 2 2 1})$. Conclusion: $\mathrm{HBeAg}$ negative cases are predominant among HBsAg-positive patients with chronic HBV infection in

"Corresponding author. 
Cameroon. With the knowledge of this epidemiology, the care of patients will be improved.

Keywords

Hepatitis B, Hepatitis B e Antigens, Viral Load, Liver Cirrhosis, Cameroon

\section{Introduction}

Cameroon, like many countries in Sub-Saharan Africa, is in a highly endemic area for the hepatitis B virus (HBV) infection. Indeed, epidemiological data from the World Health Organization (WHO) suggest that in Cameroon $8 \%-20 \%$ of the general population, or 1.6 to 4 million people are infected with HBV [1]. In the 2000s, the country adopted strategies against HBV transmission, such as the Expanded Program on Immunization including the HBV vaccine at 6 weeks of life, and the Protection from the mother to Child Transmission. Nevertheless, social and regional gaps are observed in the prevalence of the infection and in the treatment of hepatitis. Two reference Hepatitis Therapeutic Committees including the Yaoundé Committee, have been set up for the 10 regions of Cameroon.

Yaoundé, the political capital of Cameroon, is located in the central region. It covers $304 \mathrm{~km}^{2}$ and hosts a cosmopolitan population, estimated in 2005, during the 3rd population and habitat census of March 2010, at 1,817,524 inhabitants. Two Cameroonians out of three are considered as living in cities. Yaoundé is endowed with three first category hospitals making up the Yaoundé Reference Hepatitis Therapeutic Committee.

In the world, despite vaccination programs against $\mathrm{HB}$ and other effective preventive measures, more than 350 million people are affected and among them, 25\% of cases may during their lives develop hepatocellular deficiency, cirrhosis and hepatocellular carcinoma [2]-[4]. Every year in the world, 500,000 to 1,200,000 deaths are also attributable to HBV complications, mainly in Asia and Sub-Saharan Africa [2] [5]. The prognosis of the disease is related to the characteristics of the HBV infection. Thus, the prognosis of HBe antigen-negative chronic hepatitis is poor, with only a few rare cases of spontaneous remission and a low sustained response rate to antiviral treatment [6] [7]. The percentage of patients with chronic hepatitis B who are HBeAg-negative is increasing in the world with $80 \%$ - 90\% in Mediterranean areas, 20\% - 87\% in France, 30\% - 50\% in Southeast Asia and less than $10 \%$ in the United States of America and North Western Europe [2] [8]-[12].

These considerations notwithstanding, the characteristics of chronic HBV infection are not well defined in Cameroon. This ignorance is a missed opportunity for the effective case management of the disease in our country. This study used data from patients in the three hospitals constituting the Yaoundé Hepatitis Therapeutic Committee.

This eight-year cross-sectional descriptive study of care management for patients with chronic HBV infection in Yaoundé was to describe the epidemiological, biological and histological characteristics of these patients in order to optimize their care.

\section{Materials and Methods}

\subsection{Definition of Cases and Collected Variables}

Consenting consecutive HB surface antigen (HBsAg)-positive patients with chronic HBV infection and naive of antiviral treatment, consulted by gastroenterologists during the study period were eligible for the study. Chronic HBV infection is defined by the persistence of HBsAg for at least six months. This cross-sectional descriptive study was conducted from June 1, 2004 to May 31, 2012 in three hospitals in Yaoundé, Cameroon, constituting the Yaoundé Hepatitis Therapeutic Committee, by members of the Network of the Cameroon Society of Gastroenterology: Société Camerounaise de Gastroentérologie (SCGE).

The main epidemiological features (age, gender, screening date for HBsAg, alcohol abuse $>80 \mathrm{~g} / \mathrm{d}$ ), biological tests (alanine aminotransferase (ALT), HB viral load (HBV DNA levels), HBeAg status, hepatitis C virus status (HCV), Delta virus (HDV), human immunodeficiency virus (HIV)), as well as the morphology of the liver (fibrosis evaluation and cirrhosis evaluation by liver biopsy and/or fibrotest) were collected. The search for HBsAg was performed by 3rd generation ELISA, DIA-HBV ${ }^{\circledR}$ commercial kit (DiaProph.Med, Ukraine, Russia). 
The results were positive if the optical density (OD) of the test sample was greater than the OD threshold. The test was negative if the OD level was greater than the OD test sample. The HBeAg, anti-HBe antibodies, antiHCV antibodies were detected by ELISA (Biomerieux Clinical Diagnostics, Geneva, Switzerland). The antidelta antibodies were detected by EIA reactive sold by Adaltis (Rome, Italy). The level of serum HBV-DNA was determined by the COBAS AmpliPrep Technical/COBAS TaqMan HBV 2.0 Roche (Meylan, France) with a positivity threshold of $20 \mathrm{IU} / \mathrm{mL}$ (linearity of $20 \mathrm{IU} / \mathrm{mL}$ to 170 million IU/mL). Biochemical tests used to calculate the fibrotest/Actitest were made with Roche reagents (Meylan, France) on the Roche COBAS machine. The calculation of fibrosis scores was done by the website of the company Biopredictive (www.biopredictive.com) in favor of the laboratory Cerba, 95066 Cergy Pontoise Cedex 9 France (www.lab-cerba.com). Liver biopsy was performed according to the conventional subcostal trans-parietal technique under local anesthesia with lidocaine hydrochloride $1 \%$ by a gastroenterologist. Histology was performed at Centre Pasteur of Cameroon, Yaoundé.

The HBV DNA level was classified $\leq 2000 \mathrm{IU} / \mathrm{mL}$ and $>2000 \mathrm{IU} / \mathrm{mL}$, the HBV DNA was detectable at the threshold of $20 \mathrm{IU} / \mathrm{mL}$, the fibrosis score according to METAVIR [13] was classified $\leq \mathrm{F} 1$ and $>\mathrm{F} 1$, F1 matching portal fibrosis without septa, and serum alanine aminotransferase (ALT) levels were classified in two groups of patients $(1 \times$ Upper Limit of normal (ULN) $<$ ALT $<2 \times$ ULN, normal ALT group and ALT $\geq 2 \times$ ULN, elevated ALT group). The HBsAg-positive patients discovered under 6 months, the HBsAg-positive patients/positive anti-delta, HBeAg-positive/anti-HBe positive, HBeAg-negative/anti-HBe negative were not considered. Similarly co-infected HIV patients and patients with other causes of liver disease (e.g. Alcohol, metabolic, autoimmune) were excluded from the study.

\subsection{Statistical Analysis}

The data analyses were performed using SPSS 20.0 software (IBM SPSS Statistics, IBM Corporation, Armonk, NY, USA) and Microsoft Excel 2007. For quantitative variables, the means and standard deviations, medians and interquartile (IQR) were calculated. The proportions were established for categorical variables with their confidence intervals (CIs) at $95 \%$.

Comparisons of proportions were performed using $\mathrm{Chi}^{2}$ or Student test. Yates correction and the Fisher exact test were used for small numbers (at least 5). The significance level was set at 5\%.

\section{Results}

\subsection{General Characteristics of Patients (Table 1)}

Between 2004 and 2012, 328 HBsAg-positive patients with chronic HBV infection were analyzed. Out of these, 315 met the inclusion criteria. Mostly, there were men (74.6\%) and patients in the age group 20 - 39 years (65.1\%). The mean age $( \pm \mathrm{SD})$ of HBsAg-positive patients was $35.04 \pm 10.25$ years. The men were older than women (mean age of men 35.5 years and 33.8 years for women; $p=0.338$ ).

The HBeAg was negative for $92.1 \%$ [95\%CI 88.4 - 94.7] patients. The serum ALT level was elevated for $36.8 \%$ [95\%CI 31.5 - 42.4] patients, this varied according to the gender $(16.4 \%$ in female and $83.6 \%$ in male; $\mathrm{p}=$ 0.005). The HBV DNA was detected in 81.0\% [95\%CI 75.6 - 85.6] of HBsAg-positive patients. It was $>2000$ $\mathrm{UI} / \mathrm{mL}$ for 34.1\% [95\%CI 28.3 - 40.3], this result varied depending on serum ALT levels (46.6\% in patients with high serum ALT levels and $27.4 \%$ in patients with normal serum ALT levels, $\mathrm{p}=0.002)$ and gender $(17.9 \%$ in female and $33.3 \%$ in male; $p=0.04$ ), while age did not influence the hepatitis $B$ viral load $(p=0.688)$.

A liver biopsy alone or combined with Fibrotest was performed in $46.0 \%$ patients and Fibrotest alone or associated with liver biopsy was performed in $47.6 \%$ patients. A METAVIR score > F1 was found in $49.3 \%$ [95\%CI 41.1 - 57.6] Fibrotest patients, while cirrhosis was diagnosed in 6.9\% [95\%CI 3.4 - 12.3] patients with liver biopsy. This varied with the age of patients ( $0 \%$ in $<20$ years, $2.4 \%$ in $20-39$ years, $4.6 \%$ in $40-59$ years and $33.3 \%$ in $\geq 60$ years; $p=0.077$ ). Gender had no influence on the presence of cirrhosis ( $3.3 \%$ in women and $7.8 \%$ in men, $\mathrm{p}=0.687$ ).

\subsection{Comparison between HBeAg-Negative and HBeAg-Positive Patients (Table 2)}

There were 25 (7.9\%) HBeAg-positive patients and 290 (92.1\%) HBeAg-negative patients. The HBeAg-negative patients were significantly older than HBeAg-positive patients (35.3 years and 31.9 years, respectively; $\mathrm{p}=$ 0.006). No difference in the male/female ratio was observed between HBeAg-positive patients and HBeAg- 
Table 1. General features of HBsAg-positive patients in Yaoundé, Cameroon ( $\mathrm{n}=315)$.

\begin{tabular}{|c|c|c|}
\hline \multirow{2}{*}{ Features } & \multicolumn{2}{|c|}{ Results } \\
\hline & Percentage (\%) & 95\% Confidence Intervals \\
\hline Age (years) ${ }^{*}$ & $35.04 \pm 10.25$ & \\
\hline$<20$ years & 6.0 & $3.8-9.4$ \\
\hline 20 - 39 years & 65.1 & $59.5-70.3$ \\
\hline 40 - 59 years & 27.9 & $23.1-33.3$ \\
\hline$\geq 60$ years & 1.0 & $0.2-3.0$ \\
\hline Male gender & 74.6 & $69.4-79.2$ \\
\hline \multicolumn{3}{|l|}{ ALT ULN $^{\dagger}$} \\
\hline$<2$ & 63.2 & $57.6-68.5$ \\
\hline$\geq 2$ & 36.8 & $31.5-42.4$ \\
\hline \multicolumn{3}{|l|}{ HBV DNA levels $(\mathrm{IU} / \mathrm{mL})^{\ddagger}$} \\
\hline$\leq 2000$ & 65.9 & $59.7-71.7$ \\
\hline$>2000$ & 34.1 & $28.3-40.3$ \\
\hline \multicolumn{3}{|l|}{ Liver fibrosis $^{\S}$} \\
\hline$\leq \mathrm{F} 1$ & 50.7 & $42.4-58.9$ \\
\hline$>\mathrm{F} 1$ & 49.3 & $41.1-57.6$ \\
\hline Liver cirrhosis" & 6.9 & $3.4-12.3$ \\
\hline \multicolumn{3}{|l|}{ HBeAg ${ }^{* *}$} \\
\hline Positive & 7.9 & $5.3-11.6$ \\
\hline Negative & 92.1 & $88.4-94.7$ \\
\hline HBV DNA detectable & 81.0 & $75.6-85.6$ \\
\hline
\end{tabular}

${ }^{*}$ Mean \pm standard deviation; ${ }^{\dagger}$ Alanine aminotransferase, upper limit of normal; ${ }^{\dagger}$ Hepatitis B virus DNA; ${ }^{\S}$ METAVIR score on 150 patients; F1: portal fibrosis without septa; "Liver biopsy on 145 patients; ${ }^{* *}$ Hepatitis B e antigen.

Table 2. Epidemiological, biological and histological features of HBeAg-positive patients and HBeAg-negative patients in Yaoundé, Cameroon.

\begin{tabular}{|c|c|c|c|}
\hline \multirow{2}{*}{ Variables } & \multicolumn{3}{|c|}{ Patients HBeAg status } \\
\hline & HBeAg-positive & HBeAg-negative & $\mathrm{p}$ value \\
\hline Age (years) ${ }^{*}$ & $31.9 \pm 14.3$ & $35.3 \pm 9.8$ & 0.006 \\
\hline$<20$ years $(\%)$ & 20.0 & 4.8 & \\
\hline 20-39 years (\%) & 52.0 & 66.2 & \\
\hline 40-59 years (\%) & 28.0 & 27.9 & \\
\hline$\geq 60$ years $(\%)$ & 0.0 & 1.0 & 0.02 \\
\hline Female gender (\%) & 16.0 & 26.2 & 0.261 \\
\hline \multicolumn{4}{|l|}{$\operatorname{ALT~ULN}^{\dagger}(\%)$} \\
\hline$\geq 2$ & 84.0 & 32.8 & $<0.0001$ \\
\hline \multicolumn{4}{|l|}{ Liver histology (\%) } \\
\hline Liver fibrosis $^{\ddagger}>$ F1 & 69.2 & 47.4 & 0.226 \\
\hline Liver cirrhosis ${ }^{\S}$ & 15.4 & 6.1 & 0.221 \\
\hline \multicolumn{4}{|l|}{ HBV DNA levels (IU/mL) (\%) } \\
\hline$>2000$ & 100 & 29.7 & $<0.0001$ \\
\hline HBV DNA detectable ${ }^{\|}(\%)$ & 100 & 79.7 & 0.05 \\
\hline HBV DNA levels $(\mathrm{IU} / \mathrm{mL})^{* *}$ & $1550 \times 10^{3}$ & 1140 & $<0.0001$ \\
\hline
\end{tabular}

${ }^{*}$ Mean \pm standard deviation; ${ }^{\dagger}$ Alanine aminotransferase, upper limit of normal; ${ }^{\dagger}$ METAVIR score on 150 patients; F1: portal fibrosis without septa; ${ }^{\S}$ Liver biopsy on145 patients; "Hepatitis B virus DNA; ${ }^{* * *}$ Median hepatitis B viral load. 
negative patients. The serum ALT level was higher for $84.0 \%$ of HBeAg-positive patients and $32.8 \%$ of HBeAg-negative patients ( $\mathrm{p}<0.0001$ ). Among HBeAg-positive patients, $100 \%$ had detectable HBV DNA, while $79.7 \%$ of HBeAg-negative patients had detectable HBV DNA. The detectable HBV DNA proportion was significantly higher in patients with elevated serum ALT levels compared to patients with normal serum ALT levels, especially in HBeAg-positive cases. The median hepatitis B viral load was low among HBeAg-negative patients compared to HBeAg-positive patients ( $\mathrm{p}<0.0001$ ), of these $100 \%$ had a hepatitis B viral load $>2000$ $\mathrm{UI} / \mathrm{mL}(\mathrm{p}<0.0001)$.

From the point of view of the severity of liver injury, fibrosis METAVIR score $>$ F1 was found in $69.2 \%$ of HBeAg-positive patients and in $47.4 \%$ of HBeAg-negative patients without this difference being significant $(\mathrm{p}=$ 0.226). Similarly cirrhosis was diagnosed in $15.4 \%$ HBeAg-positive patients and in 6.1\% HBeAg-negative patients $(p=0.221)$. Men were more often severely affected than women $(7.8 \%$ vs. $3.3 \%$; $p=0.687)$.

\section{Discussion}

This is a descriptive study of a population of 315 HBsAg-positive patients with chronic HBV infection consulted by Cameroonian gastroenterologists in the first category hospitals of Yaoundé. At first glance it is difficult to generalize the results of this study in the overall population. There are inequalities in the prevalence of HBsAg among regions of Cameroon, and there are also social inequalities. Nevertheless, this study has the merit of being to our knowledge the first ever study addressing the issue in our environment.

This study gives us an opportunity to describe HBsAg-positive patients with chronic HBV infection and unaware of antiviral treatment, supported by a reference Hepatitis Therapeutics Committee. Knowledge is essential to optimize the care of patients. In this study HBsAg-positive patients were predominantly men in the age group of 20 - 39 years with an average age of 35.04 years and a predominant frequency of HBeAg-negative cases (92.1\%). Also, the majority of HBsAg-positive patients had normal serum ALT levels (63.2\%), a HB viral load level $\leq 2000 \mathrm{UI} / \mathrm{mL}$ (65.9\%) and severe liver histological lesions at cirrhosis in $6.9 \%$ cases at the time of the consultation.

To grasp the significance of the results of this study, it is useful to know that the distribution of academic hospitals that can handle cases of chronic HB is uneven in Cameroon. Thus, these hospitals are concentrated in Yaoundé and Douala. Therefore, these two cities drain almost all the patients treated for chronic HB in the 10 regions of Cameroon, which enables us to generalize our results. Subsequently, the majority of cases of viral HB observed in Sub-Saharan African countries, including in Cameroon have been at the stage of chronicity, because of the early horizontal predominant contamination mode, mostly due to children being infected during early childhood [14]-[16]. Indeed, the passing to chronicity rate is highly influenced by the mode of transmission. Thus, the risk of chronicity is more common and almost systematic (90\%) in the new-borns from infected mothers and 25\% - 30\% in children under 5 [14] [16]. These observations justify the status of chronic infection employed among our patients.

The results of this study are similar to those of the study we previously conducted with a population of workers [17]. They are also similar to results of previous studies in our country [18] [19] and various countries in Sub-Saharan Africa, particularly in Burkina Faso [20], Ghana [21] and Ivory Coast [22]. These various studies showed that the prevalence of HBsAg was higher in men than in women and among people less than 40 years compared with older subjects.

Most patients with chronic HBV infection managed by the Yaoundé Hepatitis Therapeutic Committee are HBeAg-negative (92.1\%). This proportion is higher than that observed in Ouagadougou, Burkina Faso (88.6\%) [23], Algeria (87\%) [24], France (87\%) [11], Italy (86.4\%) [12] and Southeast Asia (30\% - 50\%) [2]. Thus, chronic HBeAg-negative hepatitis became over time the major form of chronic HBV infections in many countries [11] [25]. In the Western world, this trend is due to the migration of populations where this form affects the majority of people, especially from the Maghreb countries to the West. Therefore, it is explained by the antiHBV vaccination coverage of the population and the specific antiviral treatments available in developed countries [26] [27]. In the African context, especially in Sub-Saharan Africa, the prevalence of HBeAg-negative cases would be the result of the natural course of the disease by HBeAg seroconversion, with disappearance of the HBeAg and the appearance of anti-HBe antibodies, and on the other hand by aging chronic HBV carriers subjects in the population [2] [14]. These chronic carriers in our environment are often contaminated during infancy by horizontal transmission [14] [28] [29]. The delay in the broadly implementation of vaccination programs at 
birth in several Sub-Saharan Africa also explains the evolution of the disease [14] [28].

This study is the first comparison of the HBeAg-positive patients and the HBeAg-negative ones in a hospital based study. Previous studies conducted in our country and dealing with the problem targeted a population of pregnant women [30]-[32]. They nevertheless provide useful information. The prevalence of HBeAg is variously reported in these studies. The study of Kfutwal et al. [30] included pregnant women of an average age of 26.2 years and no case of HBeAg-positive was found. In that of Fomulu et al. [31] pregnant women had an average age of 26.9 years and the authors reported a prevalence of HBeAg of 28\%. Finally, Ducancelle et al. [32] included pregnant women with an average age of 24.5 years in their study and reported a prevalence of $\mathrm{HBeAg}$ of $22 \%$. In our study, the overall prevalence of HBeAg was $7.9 \%$ and the specific prevalence of HBeAg related to the female gender was $5 \%$. None among the patients was pregnant and the average age was 33.8 years. This specific prevalence was higher in patients less than 20 years (12.5\%) and lower in patients between 20 - 39 years (3.8\%), 40 - 59 years (5.0\%) and none among patients of 60 and over. The influence of age in the HBeAg seroconversion is known [33] [34]. So Candotti et al. [35] reported that HBeAg seroconversion appeared in SubSaharan Africa in adolescents before the age of 15 - 16 years, which is different from the age of onset of $\mathrm{HBeAg}$ seroconversion in Asia, in average 30 - 35 years with $90 \%$ of cases before age 40 [34]. Subjects with early HBeAg seroconversion therefore are older, have an older infection and rather carry genotypes A, B, D and F than genotype C [7] [36] [37]. Genotype A (A1 and A3) is predominant in Africa, particularly sub-genotype A3 in Cameroon [38]. The patients in our study were older than those of previous studies, which could explain the differences in prevalence of HBeAg encountered.

In this study, the HBeAg-negative patients were older, mostly male, mostly had normal serum ALT levels and low serum HBV DNA concentrations compared to those with positive HBeAg. These results are identical to those in the literature [10] [39] [40]. On the contrary, hepatic lesions were more severe in positive HBeAg patients, unlike in the literature. In these patients we found $69.2 \%$ of cases of fibrosis stage $>\mathrm{F} 1,15.4 \%$ of patients with cirrhosis and a detectable HBV DNA in $100 \%$ of them, with a median of viremia of $1550 \times 10^{3} \mathrm{IU} / \mathrm{mL}$. Papatheodoidis et al. [41] reported that severe liver damages were rare in HBeAg-negative subjects whose serum ALT levels and HBV DNA concentrations are low. Therefore, the results of large population-based studies with mostly (85\%) HBeAg-negative, HBsAg-positive people older than 30 years at recruitment have shown that the risk of severe liver damage, including cirrhosis and hepatocellular carcinoma, and mortality increased proportionally with increasing viral DNA concentrations, starting with at least $1 \times 10^{4}$ copies per mL [2] [42] [43]. Apart from the high serum HBV DNA concentrations, others cirrhosis risk factors exist: male gender and advanced age [33] [42] [44], the persistence of HBeAg, genotype $C$ and persistent high serum ALT levels [37] [45] [46]. Only 32.8\% of HBeAg-negative patients had elevated serum ALT levels and 29.7\% a serum hepatitis B virus DNA levels $>2000 \mathrm{IU} / \mathrm{mL}$ in this study. These results may explain the scarcity of severe liver injury among HBeAg-negative cases in this serie.

In this study, HBV DNA was detected in $81.0 \%$ of HBsAg-positive patients. Hepatitis B viral load was $\leq 2000$ $\mathrm{UI} / \mathrm{mL}$ in $65.9 \%$ and normal serum ALT levels in $63.2 \%$. This proportion of HBV DNA is less than those reported by Sombié et al. [23] in Ouagadougou, Burkina Faso (89.4\%) and by Allain et al. [20] in Ghana (98\%). However, it is greater than that reported by Valente et al. [47] in Luanda, Angola (53\%). The differences in methods of detection of serum HBV DNA explain these results.

This work has limits. This is a cross-sectional study. Indeed, the lack of the monitoring of patients is a limitation to determine the clinico-virologic profile of the mutant virus infection. Only patients with serum HBV DNA levels at relatively high rates (29.7\%) and elevated serum ALT levels (32.8\%) above the standard at the time of the consultation have been defined by a profile. Those with fluctuations in viral replication and transaminases could not logically be well differentiated. The inactive HBV carriage could not be distinguished from others clinico-virologic profiles in the absence of scalable data, a single point measurement of HBV DNA and ALT levels. On the other hand, the data collection was difficult because of the high costs of initial examinations paid by patients without social security and because of the fear of liver biopsy.

\section{Conclusion and Recommendations}

This first study among HBsAg-positive patients of Hepatitis Therapeutics Committee in Yaoundé contributed to better describing chronic HBV infections in Cameroon. It reveals that 92.1\% of HBsAg-positive patients monitored thereby are HBeAg-negative, mostly male, and older compared with HBeAg-positive patients; they mostly 
have normal serum ALT levels and low serum hepatitis B viral load at the time of the consultation, cirrhosis seems paradoxically rare. The high prevalence of HBeAg in this study confirms that horizontal transmission is great in our milieu, so vulgarization of the Expanded Program on Immunization is needed for the prevention of HBV infection in population.

\section{Acknowledgements}

The authors thank Ms. Brigitte Wego for English editing. We thank Doctor Jean-Dominique Poveda from Laboratory Cerba, France for biological analysis, Members of the Yaoundé Hepatitis Therapeutic Committee, and Members of the Network of the Cameroon Society of Gastroenterology.

\section{Authors Contributions}

FA: study conception, design and data analysis; MK: acquisition of data, analysis and interpretation of the data; ON: statistical analyses, data interpretation and study revision; ECNN: supervision and final approval of the version to be published. All authors have read and approved the final manuscript.

\section{Competing Interests}

The authors declare there exist no competing interests.

\section{References}

[1] World Health Organization (2015) Hepatitis B. Fact Sheet No. 204. http://www.who.int/mediacentre/factsheets/fs204/en/

[2] Liaw, Y.F., Brunetto, M.R. and Hadziyannis, S.J. (2010) The Natural History of Chronic HBV Infection and Geographical Differences. Antiviral Therapy, 15, 25-33. http://dx.doi.org/10.3851/IMP1621

[3] Bekku, D., Arai, M., Imazeki, F., Yonemitsu, Y., Kanda, T., Fujiwara, K.F.K., Sato, K., Itoga, S., Nomura, F. and Yokosuka, O. (2011) Long-Term Follow-Up of Patients with Hepatitis B e Antigen Negative Chronic Hepatitis B. Journal of Gastroenterology and Hepatology, 26, 122-128. http://dx.doi.org/10.1111/j.1440-1746.2010.06322.x

[4] Fonseca, J.C.F. (2007) Natural History of Chronic Hepatitis B [Abstract]. Revista da Sociedade Brasileira de Medicina Tropical, 40, 672-677. http://dx.doi.org/10.1590/S0037-86822007000600015

[5] Lai, C.L., Ratziu, V., Yuen, M.F. and Poynard, T. (2003) Viral Hepatitis. Lancet, 3, 2089-2094. http://dx.doi.org/10.1016/S0140-6736(03)15108-2

[6] Hui, C.K. and Lau, G.K. (2007) Treatment of Hepatitis B e Antigen-Negative Patients. Current Treatment Options in Gastroenterology, 10, 474-482. http://dx.doi.org/10.1007/s11938-007-0047-6

[7] Marcellin, P., Bonino, F., Yurdaydin, C., Hadziyannis, S., Moucari, R., Kapprell, H.P., Rothe, V., Popescu, M. and Brunetto, M.R. (2013) Hepatitis B Surface Antigen Levels: Association with 5-Year Response to Peginterferon Alfa-2a in Hepatitis B e-Antigen-Negative Patients. Hepatology International, 7, 88-97. http://dx.doi.org/10.1007/s12072-012-9343-x

[8] Manesis, E.K. (2006) HBeAg-Negative Chronic Hepatitis B: From Obscurity to Prominence. Journal of Hepatology, 45, 343-346. http://dx.doi.org/10.1016/j.jhep.2006.07.001

[9] Funk, M.L., Rosenberg, D.M. and Lok, A.S. (2002) World-Wide Epidemiology of HBeAg-Negative Chronic Hepatitis B and Associated Precore and Core Promoter Variants. Journal of Viral Hepatitis, 9, 52-61. http://dx.doi.org/10.1046/j.1365-2893.2002.00304.X

[10] Chan, H.L.Y., Leung, N.W.Y., Hussain, M., Wong, M.L. and Lok, A.S.F. (2000) Hepatitis B e Antigen-Negative Chronic Hepatitis B in Hong Kong. Hepatology, 31, 763-768. http://dx.doi.org/10.1002/hep.510310330

[11] Zarski, J.P., Marcellin, P., Leroy, V., Trepo, C., Samuel, D., Ganne-Carrie, N., Barange, K., Canva, V., Doffoel, M. and Cales, P., Fédération nationale des Pôles de référence et des Réseaux Hépatites (2006) Characteristics of Patients with Chronic Hepatitis B in France: Predominant Frequency of HBe Antigen Negative Cases. Journal of Hepatology, 45, 355-360. http://dx.doi.org/10.1016/j.jhep.2006.03.007

[12] Sagnelli, E., Stroffolini, T., Mele, A., Imparato, M. and Almasio, P.L., The Italian Hospitals' Collaborating Group (2008) Chronic Hepatitis B in Italy: New Features of an Old Disease-Approaching the Universal Prevalence of Hepatitis B e Antigen-Negative Cases and the Eradication of Hepatitis D Infection. Clinical Infectious Diseases, 46, 110113. http://dx.doi.org/10.1086/524074

[13] Bedossa, P. and Poynard, T., The METAVIR Cooperative Study Group (1996) An Algorithm for the Grading of Activ- 
ity in Chronic Hepatitis C. Hepatology, 24, 289-293. http://dx.doi.org/10.1002/hep.510240201

[14] Zoulim, F. and Trepo, C. (2005) Histoire naturelle de l’hépatite B chronique. Journal de Pharmacie Clinique, 24, 233237.

[15] Dumpis, U., Holmes, E.C., Mendy, M., Hill, A., Thursz, M., Hall, A., Whittle, H. and Karayiannis, P. (2001) Transmission of Hepatitis B Virus Infection in Gambian Families Revealed by Phylogenetic Analysis. Journal of Hepatology, 35, 99-104. http://dx.doi.org/10.1016/S0168-8278(01)00064-2

[16] Lee, W.M. (1997) Hepatitis B Virus Infection. New England Journal of Medicine, 337, 1733-1745. http://dx.doi.org/10.1056/NEJM199712113372406

[17] Andoulo, F., Tagni-Sartre, M., Noah, D., Djapa, R. and Ndam, E. (2013) Prevalence of the Hepatitis B Surface Antigen in a Population of Workers in Cameroon. Open Journal of Gastroenterology, 3, 323-327. http://dx.doi.org/10.4236/ojgas.2013.38057

[18] Ndumbe, P.M. and Njie, T.K. (1989) Hepatitis A and B Infections in Yaoundé, Cameroon. Research in Virology, 140, 253-261. http://dx.doi.org/10.1016/S0923-2516(89)80102-5

[19] Mbanya, D.N., Takam, D. and Ndumbe, P.M. (2003) Serological Findings amongst First-Time Blood Donors in Yaoundé, Cameroon: Is Safe Donation a Reality or a Myth? Transfusion Medicine, 13, 267-273. http://dx.doi.org/10.1046/j.1365-3148.2003.00453.x

[20] Pietra, V., Kiema, D., Sorgho, D., Kabore, S.P., Mande, S., Castelli, F., Puoti, M. and Simpore, J. (2008) Prévalence des marqueurs du virus de l'hépatite B et des anticorps contre le virus de l'hépatite C parmi le personnel du District Sanitaire de Nanoro, Burkina Faso. Science et Technique, Sciences de la Santé, 31, 53-59.

[21] Allain, J.P., Candotti, D., Soldan, K., Sarkodie, F., Phelps, B., Giachetti, C., Shyamala, V., Yeboah, F., Anokwa, M., Owusu-Ofori, S. and Opare-Sem, O. (2003) The Risk of Hepatitis B Virus Infection by Transfusion in Kumasi, Ghana. Blood, 101, 2419-2425. http://dx.doi.org/10.1182/blood-2002-04-1084

[22] Kra, O., N’Dri, N., Ehui, E., Ouattara, B. and Bissagnene, E. (2007) Prévalence de l'antigène HBs chez les donneurs de sang au centre régional de transfusion sanguine de Bouaké (Côte d’Ivoire) en 2001. Bulletin de la Société de Pathologie Exotique, 100, 127-129.

[23] Sombié, R., Bougouma, A., Diallo, O., Bonkoungou, G., Cissé, R., Sangare, L., Sia, R., Serme, K. and Ilboudo, D. (2010) Hépatite B chronique: Aspects épidémiologique, diagnostique, thérapeutique et évolutif au centre hospitalier universitaire Yalgado Ouédraogo de Ouagadougou. Journal Africain d'Hépato-Gastroentérologie, 4, 3-10. http://dx.doi.org/10.1007/s12157-009-0137-2

[24] Khelifa, F. and Thibault, V. (2009) Characteristics of Hepatitis B Viral Strains in Chronic Carrier Patients from North-East Algeria. Pathologie Biologie, 57, 107-113. http://dx.doi.org/10.1016/j.patbio.2008.07.031

[25] Pioche, C., Brouard, C., Chevaliez, S., Alric, L., Couzigou, P., Delarocque-Astagneau, E., Denis, F., Goria, O., Guyader, D., Marcellin, P., Roudot-Thoraval, F., Roulot, D., Silvain, C., Zarski, J.P., Semaille, C. and Larsen, C. (2014) Hépatite B chronique: Prise en charge en France entre 2008 et 2011. Bulletin Épidémiologique Hebdomadaire, 12, 210-216.

[26] Ducancelle, A., Pivert, A. and Lunel-Fabiani, F. (2011) Les mutants précore et du promoteur basal du core du virus de l’hépatite B. Virologie, 15, 100-114.

[27] Rey-Cuille, M.A., Njouom, R., Bekondi, C., Seck, A., Gody, C., Bata, P., Garin, B., Maylin, S., Chartier, L., Simon, F. and Vray, M. (2013) Hepatitis B Virus Exposure during Childhood in Cameroon, Central African Republic and Senegal after the Integration of HBV Vaccine in the Expanded Program on Immunization. Pediatric Infectious Disease Journal, 32, 1110-1115. http://dx.doi.org/10.1097/INF.0b013e31829be401

[28] Botha, J.F., Ritchie, M.J., Dusheiko, G.M., Mouton, H.W. and Kew, M.C. (1984) Hepatitis B Virus Carrier State in Black Children in Ovamboland: Role of Perinatal and Horizontal Infection. The Lancet, 323, 1210-1212. http://dx.doi.org/10.1016/S0140-6736(84)91694-5

[29] Lemoine, M., Nayagam, S. and Thursz, M. (2013) Viral Hepatitis in Resource-Limited Countries and Access to Antiviral Therapies: Current and Future Challenges. Future Virology, 8, 371-380. http://dx.doi.org/10.2217/fvl.13.11

[30] Kfutwah, A.K., Tejiokem, M.C. and Njouom, R. (2012) A Low Proportion of HBeAg among HBsAg-Positive Pregnant Women with Known HIV Status Could Suggest Low Perinatal Transmission of HBV in Cameroon. Virology Journal, 9, 62. http://dx.doi.org/10.1186/1743-422X-9-62

[31] Fomulu, N.J., Morfaw, F.L.I., Torimiro, J.N., Nana, P., Mve Koh, V. and Takang, W. (2013) Prevalence, Correlates and Pattern of Hepatitis B among Antenatal Clinic Attenders in Yaoundé-Cameroon: Is Perinatal Transmission of HBV Neglected in Cameroon? BMC Pregnancy and Childbirth, 13, 158. http://dx.doi.org/10.1186/1471-2393-13-158

[32] Ducancelle, A., Abgueguen, P., Birguel, J., Mansour, W., Pivert, A., Le Guillou-Guillemette, H., Sobnangou, J.J., Rameau, A., Huraux, J.M. and Lunel-Fabian, F. (2013) High Endemicity and Low Molecular Diversity of Hepatitis B Virus Infections in Pregnant Women in a Rural District of North Cameroon. PLoS ONE, 8, e80346. 
http://dx.doi.org/10.1371/journal.pone.0080346

[33] Liaw, Y.F. and Chu, C.M. (2009) Hepatitis B Virus Infection. The Lancet, 373, 582-592. http://dx.doi.org/10.1016/S0140-6736(09)60207-5

[34] Chu, C.M. and Liaw, Y.F. (2007) Chronic Hepatitis B Virus Infection Acquired in Childhood: Special Emphasis on Prognostic and Therapeutic Implication of Delayed HBeAg Seroconversion. Journal of Viral Hepatitis, 14, 147-152. http://dx.doi.org/10.1111/j.1365-2893.2006.00810.x

[35] Candotti, D., Danso, K. and Allain, J.P. (2007) Maternofetal Transmission of Hepatitis B Virus Genotype E in Ghana, West Africa. Journal of General Virology, 88, 2686-2695. http://dx.doi.org/10.1099/vir.0.83102-0

[36] Livingston, S.E., Simonetti, J.P., Bulkow, L.R., Homan, C.E., Snowball, M.M., Cagle, H.H., Negus, S.E. and McMahon, B.J. (2007) Clearance of Hepatitis B e Antigen in Patients with Chronic Hepatitis B and Genotypes A, B, C, D, and F. Gastroenterology, 133, 1452-1457. http://dx.doi.org/10.1053/j.gastro.2007.08.010

[37] Chu, C.J., Hussain, M. and Lok, A.S. (2002) Hepatitis B Virus Genotype B Is Associated with Earlier HBeAg Seroconversion Compared with Hepatitis B Virus Genotype C. Gastroenterology, 122, 1756-1762. http://dx.doi.org/10.1053/gast.2002.33588

[38] Kurbanov, F., Tanaka, Y., Fujiwara, K., Sugauchi, F., Mbanya, D., Zekeng, L., Ndembi, N., Ngansop, C., Kaptue, L., Miura, T., Ido, E., Hayami, M., Ichimura, H. and Mizokami, M. (2005) A New Subtype (Subgenotype) Ac (A3) of Hepatitis B Virus and Recombination between Genotypes A and E in Cameroon. Journal of General Virology, 86, 2047-2056. http://dx.doi.org/10.1099/vir.0.80922-0

[39] Feld, J.J., Ayers, M., El-Ashry, D., Mazzulli, T., Tellier, R. and Heathcote, E.J. (2007) Hepatitis B Virus DNA Prediction Rules for Hepatitis B e Antigen-Negative Chronic Hepatitis B. Hepatology, 46, 1057-1070. http://dx.doi.org/10.1002/hep.21811

[40] Seo, Y., Yoon, S., Nakaji, M., Yano, Y., Nagano, H., Ninomiya, T., Hayashi, Y. and Kasuga, M. (2003) Hepatitis B Virus DNA in Anti-HBe-Positive Asymptomatic Carriers. Intervirology, 46, 43-49. http://dx.doi.org/10.1159/000068123

[41] Papatheodoridis, G.V., Manolakopoulos, S., Liaw, Y.F. and Lok, A. (2012) Follow-Up and Indications for Liver Biopsy in HBeAg-Negative Chronic Hepatitis B Virus Infection with Persistently Normal ALT: A Systematic Review. Journal of Hepatology, 57, 196-202. http://dx.doi.org/10.1016/j.jhep.2011.11.030

[42] Iloeje, U.H., Yang, H.I., Su, J., Jen, C.L., You, S.L. and Chen, C.J., The Risk Evaluation of Viral Load Elevation and Associated Liver Disease/Cancer-In HBV (The REVEAL-HBV) Study Group (2006) Predicting Cirrhosis Risk Based on the Level of Circulating Hepatitis B Viral Load. Gastroenterology, 130, 678-686. http://dx.doi.org/10.1053/j.gastro.2005.11.016

[43] Iloeje, U.H., Yang, H.I., Jen, C.L., Su, J., Wang, L.Y., You, S.L. and Chen, C.J., Risk Evaluation of Viral Load Elevation and Associated Liver Disease/Cancer-Hepatitis B Virus Study Group (2007) Risk and Predictors of Mortality Associated with Chronic Hepatitis B Infection. Clinical Gastroenterology and Hepatology, 5, 921-931. http://dx.doi.org/10.1016/j.cgh.2007.06.015

[44] Fattovich, G., Bortolotti, F. and Donato, F. (2008) Natural History of Chronic Hepatitis B: Special Emphasis on Disease Progression and Prognostic Factors. Journal of Hepatology, 48, 335-352. http://dx.doi.org/10.1016/j.jhep.2007.11.011

[45] Chu, C.M. and Liaw, Y.F. (2005) Genotype C Hepatitis B Virus Infection Is Associated with a Higher Risk of Reactivation of Hepatitis B and Progression to Cirrhosis than Genotype B: A Longitudinal Study of Hepatitis B e Antigen-Positive Patients with Normal Aminotransferase Levels at Baseline. Journal of Hepatology, 43, 411-417. http://dx.doi.org/10.1016/j.jhep.2005.03.018

[46] Tai, D.I., Lin, S.M., Sheen, I.S., Chu, C.M., Lin, D.T. and Liaw, Y.F. (2009) Long-Term Outcome of Hepatitis B e Antigen-Negative Hepatitis B Surface Antigen Carriers in Relation to Changes of Alanine Aminotransferase Levels over Time. Hepatology, 49, 1859-1867. http://dx.doi.org/10.1002/hep.22878

[47] Valente, F., do Lago, B.V., de Castro, C.A.V., de Almeida, A.J., Gomes, S.A. and Soares, C.C. (2010) Epidemiology and Molecular Characterization of Hepatitis B Virus in Luanda, Angola. Memórias do Instituto Oswaldo Cruz, 105, 970-977. http://dx.doi.org/10.1590/S0074-02762010000800004 